\title{
Association between nutritional indicators and risk of hospitalization among hemodialysis patients
}

\author{
Associação entre indicadores nutricionais \\ e risco de hospitalização em pacientes \\ em hemodiálise
}

Patrícia SZUCK ${ }^{1}$

Letícia Maria FÜHR ${ }^{1}$

Monique Ferreira GARCIA ${ }^{1}$

Angela Teodósio da SILVA'

Elisabeth WAZLAWIK ${ }^{1}$

A B S T R A C T

\section{Objective}

To verify the ability of nutritional indicators to predict risk of hospitalization in hemodialysis patients.

\section{Methods}

This prospective cohort study was conducted in two hemodialysis units in Southern Brazil. The following nutritional indicators were evaluated: subjective global assessment, malnutrition-inflammation score, nutritional risk screening 2002, percentage of body fat, mid-upper arm muscle circumference, hand grip strength, phase angle, and serum albumin. The association between nutritional indicators and risk of hospitalization over a period of two years was analyzed.

\section{Results}

One hundred thirty-eight patients $(55.4 \pm 15.2$ years, $61.6 \%$ men) were evaluated. The cumulative incidence of hospitalization during the study was $48.0 \%(95 \% \mathrm{Cl}=37.9-58.0)$. Patients hospitalized during the study period had higher body mass index and lower serum albumin than those who were not hospitalized. Based on the other indicators, malnourished patients did not have a significant risk of hospitalization ( $p>0.05)$. Serum albumin

\footnotetext{
1 Universidade Federal de Santa Catarina, Centro de Ciências da Saúde, Programa de Pós-Graduação em Nutrição. Campus Universitário, Trindade, 88040-900, Florianópolis, SC, Brasil. Correspondência para/Correspondence to: E WAZLAWIK. E-mail: <e.wazlawik@ufsc.br>.

Article based on the master's thesis of P SZUCK, intitled "Associação entre indicadores nutricionais e o risco de hospitalização em pacientes submetidos à hemodiálise”. Universidade Federal de Santa Catarina; 2014.
}

Support: Coordenação de Aperfeiçoamento de Pessoal de Nivel Superior. 
was the only predictor of hospitalization. Patients with levels $<3.8 \mathrm{~g} / \mathrm{dL}$ had a density ratio for incidence of hospitalization 2.47 times greater than those with higher levels $(p=0.003)$. Gender was a modifier of the effect ( $p$ interaction $=0.042)$, with an effect in women of $7.31(95 \% \mathrm{Cl}=2.34-22.9 ; p=0.001)$ and in men of 1.37 $(95 \% \mathrm{Cl}=0.60-3.12 ; p=0.448)$.

\section{Conclusion}

Serum albumin was able to predict the risk of hospitalization over a period of two years in female patients undergoing hemodialysis.

Keywords: Albumins. Hospitalization. Malnutrition. Nutritional assessment. Renal dialysis.

\section{R E S U M O}

\section{Objetivo}

Verificar a capacidade preditiva de indicadores nutricionais em relação ao risco de hospitalização em pacientes em hemodiálise.

\section{Métodos}

Estudo de coorte prospectivo em duas unidades de hemodiálise no Sul do Brasil. Os indicadores nutricionais avaliados foram: avaliação subjetiva global, escore de desnutrição-inflamação, rastreamento de risco nutricional 2002, percentual de gordura corporal, circunferência muscular do braço, força do aperto da mão, ângulo de fase e albumina sérica. Foi analisada a associação entre indicadores nutricionais e risco de hospitalização no período de dois anos.

\section{Resultados}

Foram avaliados 138 pacientes (55.4 15.2 anos), sendo 61.6\% homens. A incidência cumulativa de hospitalização foi $48.0 \%$ (IC95\%=37,9-58,0). Os pacientes hospitalizados durante o período do estudo apresentaram maior índice de massa corporal e menores valores de albumina sérica em comparação aos não hospitalizados. Com base nos outros indicadores, pacientes desnutridos não apresentaram risco significativo de hospitalização $(p>0,05)$. Albumina sérica foi o único preditor de hospitalização; pacientes com níveis $<3,8 \mathrm{~g} / \mathrm{dL}$ apresentaram taxa de densidade de incidência de hospitalização 2,47 vezes maior do que aqueles com níveis mais elevados ( $p=0,003)$. Sexo foi um modificador do efeito ( $p$ interação=0,042), com efeito em mulheres de 7,31 (IC95\%=2,34-22,9; $p=0,001)$ e em homens de 1,37 (IC95\%=0,60-3,12; $p=0,448)$.

\section{Conclusão}

A albumina sérica foi capaz de prever o risco de hospitalização no período de dois anos, em pacientes do sexo feminino em hemodiálise.

Palavras-chave: Albuminas. Hospitalização. Desnutrição. Avaliação nutricional. Diálise renal.

\section{INTRODUCTION}

Hemodialysis is the most common renal replacement therapy among patients with Chronic Kidney Disease (CKD), and worldwide use is increasing by approximately $7 \%$ a year ${ }^{1}$. Among the complications presented by these patients, malnutrition has a $90 \%$ prevalence ${ }^{2}$. The term protein-energy wasting specifically refers to a reduction in protein and fat mass in patients with $\mathrm{CKD}^{2}$.

Malnutrition is associated with a series of serious complications, such as infections, cardiac insufficiency, reduction in protein synthesis, and impaired wound healing ${ }^{3}$, and it increases the hospitalization rates in hemodialysis patients ${ }^{4}$. Malnourished patients have $45 \%$ longer hospital stays, and their treatment costs are on average $24 \%$ higher due to hospitalization than those of well-nourished patients ${ }^{5}$. Hemodialysis patients have hospitalization rates of up to $67 \%{ }^{6}$, which reduces quality of life and indicates a poor prognosis ${ }^{7}$.

Thus, it is important to analyze the association between malnutrition and the risk of hospitalization in hemodialysis CKD patients to 
identify the indicators associated with this risk and consequently, to enable early intervention, reducing the number of hospitalizations. Few researchers have analyzed this association ${ }^{6,8-12}$, but not in Brazil. Furthermore, apparently no study has analyzed the eight indicators evaluated herein. Therefore, the aim of this study was to verify the ability of nutritional status indicators to predict the risk of hospitalization in hemodialysis patients.

\section{METHODS}

A prospective cohort study was conducted at two nephrology clinics located in the south of Brazil. The study Protocol was approved by the local Research Ethics Committee (CAAE $n^{\circ}$ 14375113.8.0000.0121), and informed consent was obtained from each patient. The sample consisted of all male and female patients from the two nephrology clinics, recruited from April to August 2011, who agreed to participate in the study and met the inclusion criterion, which was: patients aged 19 years or more undergoing hemodialysis three times per week for at least three months. The exclusion criteria were: Body Mass Index (BMI) $\geq 34 \mathrm{~kg} / \mathrm{m}^{2}$; amputated or atrophied limbs; presence of pacemaker, cancer, stroke sequelae, or acquired immunodeficiency syndrome; hepatitis carrier; inability to answer the questions; and hospital admission at the time of the evaluation.

Clinical and sociodemographic data were collected from clinical charts and through patient interviews. The data included: gender, age, apparent skin color, education level, marital status, hemodialysis start date, hemodialysis duration, causes of $C K D$, dialysis adequacy (Kt/V), comorbidities, transplants, and biochemical tests.

The patients' nutritional status was evaluated at baseline (between April and August 2011) after hemodialysis sessions using different indicators, and the hospitalization status of the patients was verified for 24 months.
All measurements were performed after the hemodialysis session. Weight, height, Mid-Upper Arm Muscle Circumference (MUAMC), triceps skinfold thickness, subscapular skinfold thickness, suprailiac skinfold thickness, and bicipital skinfold thickness were measured by the same researcher, with prior standardization. The measurements had acceptable technical measurement errors ${ }^{13}$.

Weight was measured by a Marte ${ }^{\circledR}$ electronic scale (Marte Balanças e Aparelhos de Precisão Ltda, Santa Rita do Sapucaí, Minas Gerais, Brazil), with a maximum capacity of 150 $\mathrm{kg}$ and accuracy of $100 \mathrm{~g}$. Height was measured by a portable Sanny ${ }^{\circledR}$ stadiometer (American Medical do Brasil, São Bernardo do Campo, São Paulo, Brazil), with a length of 2 meters and accuracy of $1 \mathrm{~cm}^{14}$.

The following eight indicators were evaluated in all patients: Subjective Global Assessment (SGA), Malnutrition-Inflammation Score (MIS), Nutritional Risk Screening 2002, MUAMC, percentage of body fat, phase angle, Hand Grip Strength (HGS), and serum albumin.

The subjective global assessment investigates the patient's clinical history and physical characteristics. They were then classified as $A$ (well nourished), B (moderately malnourished or suspected of being malnourished) or C (severely malnourished) ${ }^{15}$. The patients in categories $B$ and $C$ were grouped together for the statistical analysis.

The malnutrition-inflammation score, developed specifically for dialysis patients, verifies weight gain, food intake, gastrointestinal symptoms, functional capacity, comorbidities, hemodialysis duration, subcutaneous fat, signs of muscle depletion, BMI, and biochemical tests ${ }^{16}$, and the cutoff point for malnutrition is $\geq 6$.

The nutritional risk screening 2002, developed to determine the risk of malnutrition based on BMI, recent weight loss percentage, changes in food intake, and disease severity, has a cutoff point of $\geq 3$ for nutritional risk ${ }^{17}$. 
For mid-upper arm muscle circumference, malnutrition was defined as a $>10 \%$ reduction relative to the $50^{\text {th }}$ percentile of a healthy population ${ }^{2}$. For the percentage of body fat, four skinfold thicknesses (triciptal, bicipital, subscapular, suprailiac) were measured by the Lange ${ }^{\circledR}$ adipometer (Beta Technology Incorporated Cambridge, Maryland, United States), and body densityand percentage of body fat were calculated assuming $<10 \%$ malnutrition ${ }^{2}$.

The phase angle was calculated from the resistance and reactance measured by bioelectric impedance analysis 20 minutes after the end of the hemodialysis session using a portable Biodynamics ${ }^{\circledR}$ tetrapolar device (model 310e, Biodynamics Corporation, Seattle, Washington, United States). The cutoff point ${ }^{18}$ was $<6.4^{\circ}$.

Hand grip strength was measured on the fistula-free arm by a Saehan ${ }^{\circledR}$ manual dynamometer (model SH 5001, Saehan Corporation - YangdeokDong, Masan, Korea), considering a cutoff point of $23.3 \mathrm{~kg}$, as previously established for the study participants $^{18}$.

Serum albumin, taken from the patients' medical charts, was determined by the bromocresol green method, and the patients were classified into two categories, $<3.8 \mathrm{~g} / \mathrm{dL}$ and $\geq 3.8 \mathrm{~g} / \mathrm{dL}^{2}$.

Hospitalization was defined as any hospital stay lasting one night or more. The hospital admission day was counted as a complete day of hospitalization, but the hospital discharge day was not counted. The occurrence of hospitalization was verified over 24 months.

Hospitalization data were collected from the routine clinical records, including the occurrence of hospitalization (hospitalized or not) and the frequency of hospitalization (number of times the patient was hospitalized).

The data were analyzed by a data analysis and statistical software program Stata, version 11 for Windows (Stata Corporation, College Station, Texas, United States). The data were described as absolute and relative frequencies, and average and standard deviation or median and interquartile range based on data normality. The analyses included bivariate analysis, Chi-square, Student's $t$ or Mann-Whitney association tests. Kaplan-Meier analysis and Cox regression were also performed (crude and adjusted). The following were considered possible confounders: gender, age, hemodialysis duration (in months), presence of diabetes Mellitus, and presence of systemic arterial hipertension, as they are the commonly used confounders in this type of study. The incidence density ratios (hazard ratio) were obtained from Cox regression analysis. The level of statistical significance was $p<0.05$.

\section{RES U L T S}

Hemodialysis patients totaled 204. Of these, 138 (mean age of $55.4 \pm 15.2$ years, $61.6 \%$ male) were evaluated at baseline, and 98 (mean age of $56.6 \pm 14.9$ years, $61.2 \%$ male) remained until the end of the study or until hospitalization, as shown in Figure 1. Those who refused to participate in the study did not differ from the rest of the sample in terms of mean age or gender distribution ( $p=0.62$ and $p=0.20$, respectively).

The primary diseases that led to CKD were systemic arterial hipertension (36.2\%), diabetes Mellitus (15.9\%), glomerulonephritis (13.8\%), and polycystic kidney disease (8.0\%). The remainder was undetermined (26.1\%).

During the planned monitoring period (24 months), 40 cases were terminated due to kidney transplant $(45 \%)$, transfer to another dialysis center $(25 \%)$, treatment changed to peritoneal dialysis $(15 \%)$, or death $(15 \%)$. The median monitoring duration for these subjects was 14.7 months (varying from 0.1-26.8 months), which was almost half the duration of those who completed the study (27.2 months, range 0.5-29.8 months). However, these subjects did not differ from those who completed the study in terms of mean age and gender distribution ( $p=0.132$ and $p=0.889$, respectively). 


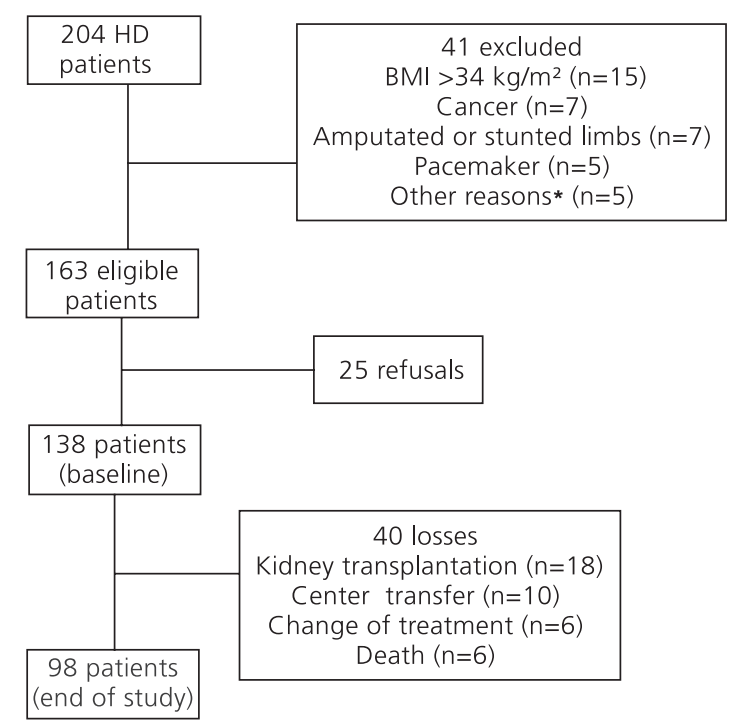

Figure 1. Patient selection process and monitoring flowchart. Florianópolis (SC), Brazil, 2013.

Nota: *Hospitalized, Hemodialysis (HD) time <3 months, stroke sequelae, inability to answer questions.

BMI: Body Mass Index.

The density incidence of hospitalization was 21.9 per 100 persons at risk per year. The cumulative incidence of hospitalization during the study was $48.0 \%(95 \% \mathrm{Cl}=37.9-58.0)$. Of the hospitalized subjects, $66.0 \%(95 \% \mathrm{Cl}=57.4-73.8)$ were admitted only once, $21.3 \%(95 \% \mathrm{Cl}=14.5-28.8)$, twice, and $12.7 \%(95 \% \mathrm{Cl}=7.9-19.8)$, three times or more. The greatest frequency of hospitalization was five times $(n=2)$.

Table 1 shows the main clinical characteristics of the patients at baseline and a comparison of these parameters by hospitalization status. Of the hospitalized patients, women had significantly lower phase angle $(p=0.015)$ and HGS $(p=0.001)$ than men.

Hospitalized patients had higher BMI (difference between means 1.6, 95\% Cl=2.9-0.3) than those who were not hospitalized, with no difference in the percentage of body fat, mid-upper arm circumference or MUAMC.

Only albumin was significantly lower in hospitalized patients (difference between means $0.10,95 \% \mathrm{Cl}=0.00-0.20 ; p=0.04)$.
Approximately one-third of the patients had diabetes Mellitus or heart disease, and over $80 \%$ systemic arterial hipertension. These percentages were similar for hospitalized and nonhospitalized subjects.

In terms of dialysis parameters, the hemodialysis dose and duration were similar for hospitalized and non-hospitalized patients.

Table 2 shows the prevalence of malnutrition at baseline according to each nutritional indicator. The lowest percentage stemmed from the Nutritional Risk Screening 2002, and the highest, from phase angle. Of all the study criteria, only the prevalence of malnutrition based on albumin level was higher in hospitalized patients. Based on percentage of body fat (cutoff point $<10 \%$ for malnutrition), no individual was malnourished.

The Kaplan Meier graphs, which evaluated the association between hospitalization and malnutrition over 24 months, showed that albumin was the indicator with good differentiation and proportionality in the risk of hospitalization assessment (Figure 2) ( $p=0.003)$.

Table 3 shows the results of the analyses (crude and adjusted) of each nutritional indicator and hospitalization incidence density.

Patients with serum albumin $<3.8 \mathrm{~g} / \mathrm{dL}$ had a 2.47 times higher hazard ratio of hospitalization than those with higher levels ( $p=0.003)$. Gender was a modifier of effect ( $p$ interaction $=0.042$ ), in the adjusted analysis the hazard ratio for hospitalization was $7.31(95 \% \mathrm{Cl}=2.34-22.9)$ times higher in female patients with albumin levels $<3.8 \mathrm{~g} / \mathrm{dL}$ than in those with higher levels $(p=0.001)$. For men, the corresponding hazard ratio was $1.37(95 \% \mathrm{Cl}=0.60-3.12)$; however, this risk was not statistically significant $(p=0.448)$. These differences can be observed in Figure 2, which shows that women with albumin levels $\geq 3.8 \mathrm{~g} / \mathrm{dL}$ have lower risk of hospitalization than their male counterparts, while women with albumin levels $<3.8 \mathrm{~g} / \mathrm{dL}$ presented the worst 
Table 1. Baseline characteristics and comparison of hospitalized and non-hospitalized patients. Florianópolis (SC), Brazil, 2011.

\begin{tabular}{|c|c|c|c|}
\hline \multirow{2}{*}{ Characteristics } & \multicolumn{3}{|c|}{ Mean (standard deviation) } \\
\hline & Total sample $(n=138)$ & Non-hospitalized $(\mathrm{n}=91)$ & Hospitalized $(n=47)$ \\
\hline Age (years) & $55.4 \pm 15.2$ & $53.9 \pm 15.3$ & $58.3 \pm 14.6$ \\
\hline $\operatorname{Sex}(n, \%$ men $)$ & 61.6 & 62.6 & 59.6 \\
\hline Skin color (n, \% whites) & 69.6 & 74.7 & 59.6 \\
\hline Schooling, $\% \geq 9$ years) & 38.4 & 44.0 & 27.6 \\
\hline Marital status (n, \% with partner) & 61.6 & 61.5 & 61.7 \\
\hline \multicolumn{4}{|l|}{ Nutritional parameters } \\
\hline Weight (kg) & $65.5 \pm 12.5$ & $63.9 \pm 11.2$ & $68.7 \pm 14.2^{*}$ \\
\hline Height $(\mathrm{cm})^{\dagger}$ & $162.3 \pm 10.0$ & $162.0 \pm 9.6$ & $163.1 \pm 10.9$ \\
\hline Body mass index $\left(\mathrm{kg} / \mathrm{m}^{2}\right)^{\dagger}$ & $24.8 \pm 3.8$ & $24.3 \pm 3.4$ & $25.9 \pm 4.2^{*}$ \\
\hline Body fat (\%) & $32.6 \pm 6.7$ & $32.0 \pm 6.9$ & $33.8 \pm 6.0$ \\
\hline MUAC $(\mathrm{cm})$ & $27.8 \pm 3.8$ & $27.4 \pm 3.6$ & $28.6 \pm 4.1$ \\
\hline MUAMC $(\mathrm{cm})$ & $23.3 \pm 2.8$ & $23.1 \pm 2.7$ & $23.9 \pm 3.0$ \\
\hline Hand grip strength $(\mathrm{kg})$ & $25.8 \pm 11.3$ & $26.2 \pm 11.7$ & $24.9 \pm 10.4$ \\
\hline Phase angle ${ }^{o \neq}$ & $6.4 \pm 1.3$ & $6.5 \pm 1.2$ & $6.2 \pm 1.6$ \\
\hline Albumin $(\mathrm{g} / \mathrm{dL})^{\dagger}$ & $3.9 \pm 0.3$ & $4.0 \pm 0.3$ & $3.9 \pm 0.3^{*}$ \\
\hline \multicolumn{4}{|l|}{ Comorbidity } \\
\hline Diabetes Mellitus - n (\%) & $41(29.7)$ & $25(27.5)$ & $16(34.0)$ \\
\hline Systemic arterial hipertension - $\mathrm{n}(\%)$ & $113(81.9)$ & $71(78.0)$ & $42(89.4)$ \\
\hline Heart disease - $n(\%)$ & $41(29.7)$ & $26(28.6)$ & $15(31.9)$ \\
\hline \multicolumn{4}{|l|}{ Dialysis parameters } \\
\hline Dialysis dose $(\mathrm{KtN})^{\S}$ & $1.4 \pm 0.2$ & $1.4 \pm 0.2$ & $1.3 \pm 0.2$ \\
\hline Hemodialysis duration (months- median [IR]) & $35.9 \quad 12.9 ; 77.1$ & $37.112 .9 ; 74.0$ & $30.912 .9 ; 84.6$ \\
\hline Arteriovenous fistula - n (\%) & $96(69.6)$ & $76(83.5)$ & $29(84.4)$ \\
\hline \multicolumn{4}{|l|}{ Laboratory parameters } \\
\hline Phosphorus (mg/dL) & $6.1 \pm 1.3$ & $5.9 \pm 1.2$ & $6.3 \pm 1.5$ \\
\hline Potassium (mg/dL) & $5.5 \pm 0.8$ & $5.4 \pm 0.8$ & $5.6 \pm 0.7$ \\
\hline Pre-dialysis urea (mg/dL) & $156.9 \pm 34.6$ & $157.5 \pm 25.8$ & $155.8 \pm 27.6$ \\
\hline Post-dialysis urea (mg/dL) & $50.3 \pm 16.2$ & $50.4 \pm 12.9$ & $50.1 \pm 13.6$ \\
\hline
\end{tabular}

Note: The $p$ value is for comparison between hospitalization groups. ${ }^{*} p<0.05$; ${ }^{+}$Data on 1 patient lost; ${ }^{\ddagger}$ Data on 13 patients lost; ${ }^{\S}$ Data on 11 patients lost; ${ }^{\circ}$ Degree.

MUAMC: Mid-Upper Arm Muscle Circumference; IR: Interquartile Range; MUAC: Mid-Upper Arm Circumference.

Table 2. Prevalence of malnutrition according to each nutritional indicator. Florianópolis (SC), Brazil, 2011.

\begin{tabular}{|c|c|c|c|c|c|c|}
\hline \multirow{2}{*}{ Nutritional indicator } & \multicolumn{2}{|c|}{ Total sample $(n=138)$} & \multicolumn{2}{|c|}{ Non-hospitalized $(\mathrm{n}=91)$} & \multicolumn{2}{|c|}{ Hospitalized $(n=47)$} \\
\hline & $n$ & $\%$ & $n$ & $\%$ & $\mathrm{n}$ & $\%$ \\
\hline Low MUAMC (>10.0\%) & 71 & 51.5 & 43 & 47.3 & 28 & 59.6 \\
\hline Hand grip strength $(<23.3 \mathrm{~kg})$ & 61 & 44.2 & 39 & 42.9 & 22 & 46.8 \\
\hline Phase angle $\left(<6.4^{\circ}\right)^{*}$ & 81 & 58.4 & 48 & 53.0 & 32 & 69.1 \\
\hline Albumin $(<3.8 \mathrm{~g} / \mathrm{dL})^{\dagger}$ & 45 & 32.9 & 23 & 25.3 & 22 & $47.8^{4}$ \\
\hline$S G A(B+C)$ & 49 & 35.5 & 31 & 34.1 & 18 & 38.3 \\
\hline MIS ( $\geq 6$ points $)^{\S}$ & 61 & 44.1 & 37 & 40.7 & 24 & 51.1 \\
\hline NRS ( $\geq 3$ points) & 37 & 26.8 & 20 & 22.0 & 17 & 36.2 \\
\hline
\end{tabular}

Note: " Data on 13 patients lost; ${ }^{\dagger}$ Data on 1 patient lost; ${ }^{\ddagger} p<0.05 ;{ }^{5}$ Data on 2 patients lost.

MUAMC: Mid-Upper Arm Muscle Circumference; MIS: Malnutrition-Inflammation Score; NRS 2002: Nutritional Risk Screening 2002; SGA: Subjective Global Assessment.

prognosis. The mean albumin level of men and women did not differ $(3.98 \pm 0.31 \mathrm{~g} / \mathrm{dL}$ versus $3.93 \pm 0.22 \mathrm{~g} / \mathrm{dL}$, respectively, $p=0.339)$, even when only patients with albumin levels $<3.8 \mathrm{~g} / \mathrm{dL}$ were considered $(3.57 \pm 0.23$ versus $3.62 \pm 0.11 \mathrm{~g} / \mathrm{dL}$, respectively, $p=0.737)$. 


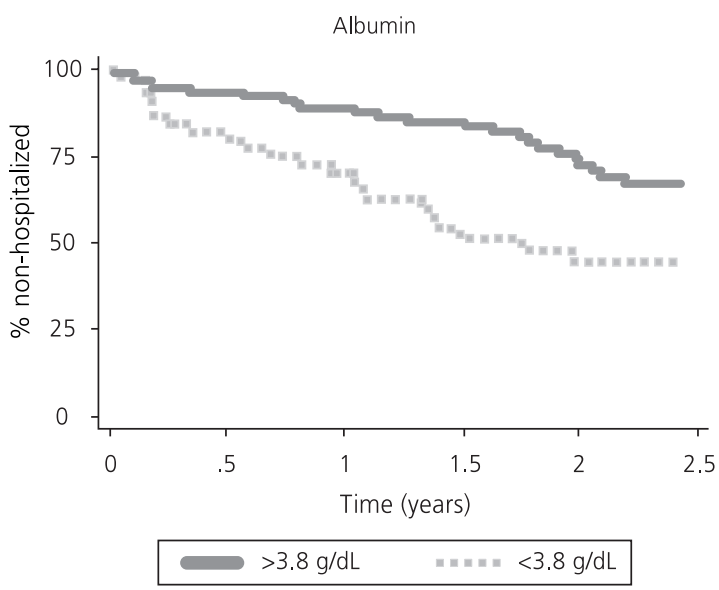

B

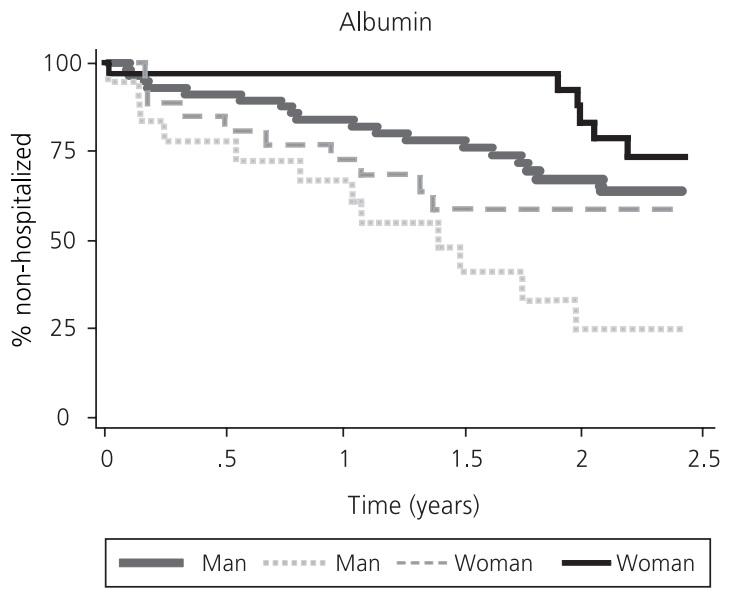

Figure 2. Kaplan Meier curves showing the association between albumin levels and risk of hospitalization in hemodialysis patients (A). Kaplan Meier curves showing the association between albumin levels and risk of hospitalization in hemodialysis patients stratified by gender (B). Florianópolis (SC), Brazil, 2013.

Table 3. Hazard ratio for hospitalization over 24 months according to nutritional indicators. Florianópolis (SC), Brazil, 2013.

\begin{tabular}{lcccccc}
\hline \multirow{2}{*}{ Indicator (cutoff point) } & \multicolumn{5}{c}{ Hazard ratio $(95 \% \mathrm{Cl})$} \\
\cline { 2 - 7 } & \multicolumn{2}{c}{ Raw analysis } & $p$ & \multicolumn{2}{c}{ Adjusted analysis $^{*}$} & $p$ \\
\hline Low MUAMC $(>10.0 \%)$ & 1.57 & $0.88 ; 2.81$ & 0.130 & 1.56 & $0.81 ; 3.01$ & 0.187 \\
Hand grip strength $(<23.3 \mathrm{~kg})$ & 1.18 & $0.66 ; 2.09$ & 0.577 & 1.09 & $0.52 ; 2.29$ & 0.819 \\
Phase angle $\left(<6.4^{\circ}\right)^{\dagger}$ & 1.68 & $0.87 ; 3.23$ & 0.121 & 1.43 & $0.70 ; 2.90$ & 0.326 \\
Albumin $(<3.8 \mathrm{~g} / \mathrm{dL})^{\ddagger}$ & 2.42 & $1.35 ; 4.33$ & 0.003 & 2.47 & $1.37 ; 4.44$ & 0.003 \\
SGA $(\mathrm{B}+\mathrm{C})$ & 1.01 & $0.56 ; 1.83$ & 0.964 & 0.94 & $0.51 ; 1.72$ & 0.834 \\
MIS $(\geq 6)^{\S}$ & 1.31 & $0.73 ; 2.34$ & 0.372 & 1.31 & $0.73 ; 2.37$ & 0.368 \\
NRS 2002 $(\geq 3)$ & 1.60 & $0.88 ; 2.91$ & 0.120 & 1.53 & $0.83 ; 2.83$ & 0.171 \\
\hline
\end{tabular}

Note: Values are presented as hazard ratio and $95 \% \mathrm{Cl}$. Values for the hazard ratio are in comparison with individuals classified as well nourished (reference groups) according to each indicator. "Adjusted for the variables gender, age, hemodialysis time, presence of diabetes Mellitus, and presence of systemic arterial hipertension; ${ }^{\dagger}$ Data for 13 patients lost; ${ }^{\ddagger}$ Data for 1 patient lost; ${ }^{\S}$ Data for 2 patients lost.

MUAMC: Mid-Upper Arm Muscle Circumference; MIS: Malnutrition-Inflammation Score; SGA: Subjective Global Assessment; NRS 2002: Nutritional Risk Screening 2002

\section{I S C U S S I O N}

In this study the prevalence of malnutrition varied from 27 to $69 \%$, depending on indicator. Malnutrition can increase the hospitalization rates of hemodialysis patients ${ }^{4}$, so the patient's nutritional status has to be properly assessed by suitable indicators ${ }^{19}$ to allow appropriate dietetic intervention. Almost half the patients were hospitalized at least once during the study period. Serum albumin was the only indicator capable of predicting risk of hospitalization, but this effect was modified by gender, so only capable in women.

The study variability in the prevalence of malnutrition has also been reported by another study ${ }^{20}$. This variation may stem from different cutoff points and nutritional indicators, which suggests that each indicator evaluates a different aspect of nutritional status, indicating the importance of using a set of indicators to evaluate hemodialysis CKD patients ${ }^{21}$.

During the two-year monitoring period, $48.0 \%$ of the patients were hospitalized at least 
once, and the maximum number of hospitalizations was five. The hospitalization incidence density during a period of one year was $21.9 \%$. This percentage is similar to that found by a Thai study, in which $28.0 \%$ of the patients had been hospitalized at least once during a period of 12 months, and lower than that reported by a Taiwanese study $(40.0 \%)^{10}$. The percentage of hospitalization of hemodialysis patients in North America varied from 51.0 to $67.0 \% 4,9,11,22$. This difference may be due to the smaller sample size ${ }^{21}$ and shorter hemodialysis duration ${ }^{9,11}$ compared with this study. In most studies the sample's mean age and gender distribution were similar to those of this study, with mean ages varying from 54.5 to 59.4 years, and percentage of male patients varying from 53.0 to $62.0 \% 4,9,11,22$. In addition, most studies monitored the patients for 12 months ${ }^{9-12}$, but one monitored for 15 months ${ }^{4}$ and another, for 18 months ${ }^{22}$.

Although the number of monitored patients decreased during the study, the median monitoring duration of the patients who did not finish the study was 14.7 months, that is, greater than the 12 months observed in other studies 9,11,12. This type of research has common reasons for losses; for instance, in a French study the most common causes for not continuing treatment were kidney transplant (63\%), transfer to another dialysis center $(20 \%)$, and death $(17 \%)^{23}$.

Serum albumin was the only indicator capable of predicting the risk of hospitalization in hemodialysis patients. The patients with albumin values $<3.8 \mathrm{~g} / \mathrm{dL}$ had a hospitalization density incidence 2.47 times greater than those with higher levels. Other studies in the United States ${ }^{4,9,10,24}$, Germany ${ }^{25}$, Spain ${ }^{26}$, Australia ${ }^{8}$, and Taiwan $^{10}$ also reported lower albumin levels in hospitalized hemodialysis patients.

The synthesis of albumin decreases during malnutrition ${ }^{27}$. However, this indicator may be associated with inflammation ${ }^{28}$ because it is a negative acute-phase protein, and its synthesis is suppressed during inflammation regardless of nutritional status ${ }^{29}$. Therefore, the use of albumin for evaluating the nutritional status of renal patients is limited ${ }^{27,30}$. Nevertheless, albumin is an important predictor of poor prognosis regardless of nutritional or inflammatory status. A serum albumin reduction of $1.0 \mathrm{~g} / \mathrm{dL}$ significantly increased the chances of mortality (137\%) and morbidity (89\%), as well as the need of long-term intensive care $(28 \%)$ or hospitalization $(71 \%)^{31}$.

Furthermore, nutritional intervention increases serum albumin levels regardless of inflammatory status ${ }^{32,33}$, and serum albumin increases of $0.2 \mathrm{~g} / \mathrm{dL}$ or $0.4 \mathrm{~g} / \mathrm{dL}$ reduce the risk of hospitalization by 25 and $41 \%$, respectively, in hemodialysis patients ${ }^{24}$.

The hospitalization hazard ratio based on serum albumin was 7.31 for women and only 1.37 for men. No reports were found in the literature to explain this finding. This reflects the limitations of albumin measurements as markers of nutritional status. However, it also suggests that, in this population, albumin levels reflect fundamentally different clinical processes. One hypothesis in this regard is that the cut-off point for albumin may differ by gender. Thus, men may have a higher cutoff point $(>3.8 \mathrm{~g} / \mathrm{dL})$ than women. Further studies are needed to explain this difference.

In relation to body composition, women had a higher percentage of body fat than men (35.4 \pm 0.9 and $30.8 \pm 0.7$, respectively, $p<0.001$ ), and a lower percentage of fat-free body mass than men $(64.5 \pm 0.9$ and $69.2 \pm 0.7$, respectively, $p<0.001)$, as well as lower HGS than men $(16.5 \pm 0.8$ and $28.8 \pm 1.2, p<0.001)$, indicating smaller muscle mass.

No association between the other indicators and risk of hospitalization was found, even after adjusting for the confounders commonly used in similar studies.

The study SGA-related data were consistent with those of another study ${ }^{12}$, which found no association between this indicator and 
hospitalization rate. However, SGA has been significantly associated with the number, frequency, and length of hospitalization, or risk of first hospitalization event, although these studies had higher hemodialysis duration (in months) and monitoring duration 8,16,25.

The cut-off points of studies where MIS was associated with risk of hospitalization ${ }^{11,12}$ differed from those of this study. MIS was either graded every 5 points in the form of a quartile or with a cutoff point of $\geq 8$. A study of Thai patients ${ }^{12}$ that used the same cutoff point as this study did not find an association with hospitalization, despite the longer hemodialysis duration (in months).

A German study of hemodialysis patients found that patients at nutritional risk according to the Nutritional Risk Screening 2002 experienced a significant increase in hospitalization frequency and length of hospital stay, and that phase angle was only capable of predicting hospitalization frequency ${ }^{25}$. This difference may be explained by the one-year longer monitoring duration of the study.

Although hand grip strength is a functional test, and the result may reflect loss of body proteins ${ }^{34}$, no association was found between HGS and risk of hospitalization. Studies that investigated this association in hemodialysis patients were not found.

One of the limitations of this study was the sample size, restricted to 138 patients, which reduced the capacity of the statistical analysis of some results. The absence of food intake assessment was also a limitation because protein-energy wasting could not be diagnosed. A lack of data on the causes of hospitalization limited the amount of information about the clinical conditions of the patient. In addition, the lack of C-reactive protein analysis meant that the inflammatory status of the patients was unknown. Although $15 \%$ of the patients refused to participate in the study and $29 \%$ were not monitored until the end of the study, the sample was representative of the source population, given that the mean age and gender distribution of these patients were similar to those of the participants who finished the study. Moreover, the time at risk was a cutoff point of the study because it considers the time for which each patient contributed to the study, which reduced possible errors associated with subjects who were not monitored until the end of the study. Thus, the data need to be used with more caution than those of other patients, necessarily considering the participants' sociodemographic profile and health conditions.

Given that distinct indicators relate to different aspects of nutritional status, using a set of indicators increases the accuracy of hemodialysis patient assessment. The study hospitalization rate was high, and the cumulative incidence of hospitalization during the study was $48 \%$. The only indicator capable of predicting hospitalization was serum albumin, but only in women. This result is important as this indicator is included in routine exams. Thus, this factor should be considered in risk-of-hospitalization assessment, allowing early intervention to reduce the number of hospitalizations. However, the potential utility of other study indicators cannot be discarded because a larger sample and longer monitoring duration may provide significant results.

In conclusion hospitalization rate was high among the study patients, and albumin was a predictor of hospitalization in female hemodialysis patients.

\section{CONTRIBUTORS}

P SZUCK made a substantial contribution to study design, data collection and analysis, manuscript writing and approval of the final version. E WAZLAWIK made a substantial contribution to study design, and manuscript writing and approval of the final version. LM FÜHR, MF GARCIA, and AT SILVA participated in data collection; manuscript writing, significant advice, and approval of the final version. 


\section{REFERENCES}

1. Grassmann A, Gioberge S, Moeller S, Brown G. ESRD patients in 2004: Global overview of patient numbers, treatment modalities and associated trends. Nephrol Dial Transplant. 2005; 20:2587-93. http://dx.doi.org/10.1093/ndt/gfi159

2. Fouque D, Kalantar-Zadeh K, Kopple J, Cano N, Chauveau P, Cuppari L, et al. A proposed nomenclature and diagnostic criteria for proteinenergy wasting in acute and chronic kidney disease. Kidney Int. 2008; 73(4):391-8. http://dx.doi.org/ 10.1038/sj.ki.5002585

3. Acuña K, Cruz T. Avaliação do estado nutricional de adultos e idosos e situação nutricional da população brasileira. Arq Bras Endocrinol Metab. 2004; 48(3):345-61.

4. Ikizler TA. Optimal nutrition in hemodialysis patients. Adv Chronic Kidney Dis. 2013; 20(2):181-9. http://dx.doi.org/10.1053/j.ackd.2012.12.002

5. Lim SL, Ong KCB, Chan YH, Loke WC, Ferguson $M$, Daniels L. Malnutrition and its impact on cost of hospitalization, length of stay, readmission and 3-year mortality. Clin Nutr. 2012; 31(3):345-50. http://dx.doi.org/10.1016/j.clnu.2011.11.001

6. Ikizler TA, Wingard RL, Harvell J, Shyr Y, Hakim RM. Association of morbidity with markers of nutrition and inflammation in chronic hemodialysis patients: A prospective study. Kidney Int. 1999; 55(5):1945-51. http://dx.doi.org/10.1046/j.1523-1755.1999.00 410.x

7. Daratha $K B$, Short RA, Corbett $C F$, Ring ME, Alicic $R$, Choka $R$, et al. Risks of subsequent hospitalization and death in patients with kidney disease. Clin J Am Soc Nephrol. 2012; 7(3):40916. http://dx.doi.org/10.2215/CJN.05070511

8. Laws RA, Tapsell LC, Kelly J. Nutritional status and its relationship to quality of life in a sample of chronic hemodialysis patients. J Ren Nutr. 2000; 10(3):139-47. http://dx.doi.org/10.1053/jren.2000. 7412

9. Kalantar-Zadeh K, Kopple JD, Block G, Humphreys $\mathrm{MH}$. Association among SF36 quality of life measures and nutrition, hospitalization, and mortality in hemodialysis. J Am Soc Nephrol. 2001; 12(12):2797-806.

10. Chiang CK, Hsu SP, Pai MF, Peng YS, Ho TI, Liu SH, et al. Interleukin-18 is a strong predictor of hospitalization in haemodialysis patients. Nephrol Dial Transplant. 2004; 19(11):2810-15. http://dx. doi.org/10.1093/ndt/gfh475

11. Kalantar-Zadeh K, Block G, McAllister CJ, Humphreys $\mathrm{MH}$, Kopple JD. Appetite and inflammation, nutrition, anemia, and clinical outcome in hemodialysis patients. Am J Clin Nutr. 2004; 80(2):299-307.

12. Pisetkul C, Chanchairujira K, Chotipanvittayakul N, Ong-Ajyooth L, Chanchairujira T. Malnutritioninflammation score associated with atherosclerosis, inflammation and short-term outcome in hemodialysis patients. J Med Assoc Thai. 2010; 93(1):147-56.

13. Habicht J. Estandarización de métodos epidemiológicos cuantitativos sobre el terreno. Bol Oficina Sanit Panam. 1974; 76(5):375-84.

14. World Health Organization. Physical status: The use and interpretation of anthropometry. Geneva: WHO; 1995.

15. Detsky AS, McLaughlin JR, Baker JP, Johnston N, Whittaker S, Mendelson RA, et al. What is subjective global assessment of nutritional status? J Parenter Enteral Nutr. 1987; 11(1):8-13. http:// dx.doi.org/10.1177/014860718701100108

16. Kalantar-Zadeh K, Kopple JD, Block G, Humphreys $\mathrm{MH}$. A malnutrition-inflammation score is correlated with morbidity and mortality in maintenance hemodialysis patients. Am J Kidney Dis. 2001; 38(6):1251-63. http://dx.doi.org/10.1053/ajkd. 2001.29222

17. Kondrup J, Rasmussen HH, Hamberg O, Stanga Z, Ad Hoc ESPEN Working Group. Nutritional risk screening (NRS 2002): A new method based on an analysis of controlled clinical trials. Clin Nutr. 2003; 22(3):321-36. http://dx.doi.org/10.1016/S0261-5 614(02)00214-5

18. Garcia MF, Wazlawik E, Moreno YMF, Führ LM, González-Chica DA. Diagnostic accuracy of handgrip strength in the assessment of malnutrition in hemodialyzed patients. e-SPEN J. 2013; 8(4):181-6. http://dx.doi.org/10.1016/j.clnme.2013.06.003

19. Barbosa-Silva MC. Subjective and objective nutritional assessment methods: What do they really assess? Curr Opin Clin Nutr Metab Care. 2008; 11(3):248-54. http://dx.doi.org/10.1097/MCO. 0b013e3282fba5d7

20. Kopple JD, Greene T, Chumlea WC, Hollinger D, Maroni BJ, Berril D, et al. Relationship between nutritional status and the glomerular filtration rate: Results from the MDRD Study. Kidney Int. 2000; 57(4):1688-703. http://dx.doi.org/10.1046/ j.1523-1755.2000.00014.x

21. Cuppari L, Kamimura MA. Avaliação nutricional na doença renal crônica: desafios na prática clínica. J Bras Nefrol. 2009; 31(1):28-35.

22. Block GA, Klassen PS, Lazarus JM, Ofsthun N, Lowrie EG, Chertow GM. Mineral Metabolism, Mortality, and Morbidity in Maintenance Hemodialysis. J Am Soc Nephrol. 2004; 15(8):2208-18. http:// dx.doi.org/10.1097/01.ASN.0000133041.27682. A2 
23. Arkouche W, Traeger J, Delawari E, Sibaï-Galland R, Abdullah E, Galland R, et al. Twenty-five years of experience with out-center hemodialysis. Kidney Int. 1999; 56(6):2269-75. http://dx.doi.org/10. 1046/j.1523-1755.1999.00771.x

24. Lacson EJ, Ikizler TA, Lazarus JM, Teng M, Hakim RM. Potential impact of nutritional intervention on end-stage renal disease hospitalization, death, and treatment costs. J Ren Nutr. 2007; 17(6):363-71. http://dx.doi.org/10.1053/j.jrn.2007.08.009

25. Fiedler R, Jehle PM, Osten B, Dorligschaw O, Girnd $M$. Clinical nutrition scores are superior for the prognosis of haemodialysis patients compared to lab markers and bioelectrical impedance. Nephrol Dial Transplant. 2009; 24(12):3812-7. http://dx.doi. org/10.1093/ndt/gfp346

26. Marcén R, Teruel JL, de la Cal MA, Gámez C. The impact of malnutrition in morbidity and mortality in stable haemodialysis patients. Spanish Cooperative Study of Nutrition in Hemodialysis. Nephrol Dial Transplant. 1997; 12(11):2324-31. http://dx.doi. org/10.1093/ndt/12.11.2324

27. Santos NSJ, Draibe SA, Kamimura MA, Canziani ME, Cendorogolo M, Garcia Júnior A, et al. Is serum albumin a marker of nutritional status in hemodialysis patients without evidence of inflammation? Artif Organs. 2003; 27(8):681-6. http://dx.doi.org/10.10 46/j.1525-1594.2003.07273.x

28. Kaysen GA, Dubin JA, Müller HG, Mitch WE, Rosales LM, Levin NW. Relationships among inflammation nutrition and physiologic mechanisms establishing albumin levels in hemodialysis patients. Kidney Int. 2002; 61(6):2240-9. http://dx.doi.org/ 10.1046/j. 1523-1755.2002.00076.x
29. Don BR, Kaysen GA. Assessment of inflammation and nutrition in patients with end-stage renal disease. J Nephrol. 2000; 13(4):249-59.

30. Mutsert R, Grootendorst DC, Indemans F, Boeschoten EW, Krediet RT, Dekker FW, et al. Association between serum albumin and mortality in dialysis patients is partly explained by inflammation, and not by malnutrition. J Ren Nutr. 2009; 19(2):127-35. http://dx.doi.org/10.1053/j. jrn.2008.08.003

31. Vincent J, Dubois M, Navickis RJ, Wilkes MM. Hypoalbuminemia in acute illness: Is there a rationale for intervention? A meta-analysis of cohort studies and controlled trials. Ann Surg. 2003; 237(3):319-34. http://dx.doi.org/10.1097/01.SLA.0 000055547.93484 .87

32. Leon JB, Majerle AD, Soinski JA, Kushner I, OhriVachaspati $P$, Sehgal AR. Can a nutrition intervention improve albumin levels among hemodialysis patients? A pilot study. J Ren Nutr. 2001; 11(1):9-15. http://dx.doi.org/10.1016/S1051-2276(01)79890-1

33. Leon JB, Albert JM, Gilchrist G, Kushner I, Lerner E, Mach $S$, et al. Improving albumin levels among hemodialysis patients: A community-based randomized controlled trial. Am J Kidney Dis. 2006; 48(1):28-36. http://dx.doi.org/10.1053/j.ajkd.2006. 03.046

34. Schlüssel MM, Anjos LA, Kac G. A dinamometria manual e seu uso na avaliação nutricional. Rev Nutr. 2008; 21(2):223-35. http://dx.doi.org/10.1590/ S1415-52732008000200009

Received: April 9, 2015

Final version: November 26, 2015 Approved: December 23, 2015 
